\title{
Interactive comment on "Retrieval of Gridded Aerosol Direct Radiative Forcing Based on Multiplatform Datasets” by Yanyu Wang et al.
}

\section{Yanyu Wang et al.}

oxeye75@163.com

Received and published: 5 November 2019

The reply to anonymous referee \#2 is uploaded as a supplement file.

Please also note the supplement to this comment:

https://www.atmos-meas-tech-discuss.net/amt-2019-311/amt-2019-311-AC2-

supplement.pdf

Interactive comment on Atmos. Meas. Tech. Discuss., doi:10.5194/amt-2019-311, 2019. 